Int. J. Morphol.,

33(3):855-859, 2015.

\title{
Scanning Electron Microscopic Study of the Lingual Papillae in the Anatolian Water Buffalo
}

\author{
Estudio de las Papilas Linguales en el Búfalo de Agua \\ de Anatolia por Microscopía Electrónica de Barrido
}

M. Can* \& S. H. Atalgı*

CAN, M. \& ATALGIN, S. H. Scanning electron microscopic study of the lingual papillae in the Anatolian water buffalo. Int. J. Morphol., 33(3):855-859, 2015.

SUMMARY: The purpose of this study was to describe the surface structure of the lingual papillae in Anatolian Water Buffaloes using SEM. Six male Anatolian Water Buffaloes were used. Filiform, lentiform and conical papillae were determined three types as mechanical papillae. Fungiform and vallate papillae were observed two types as gustatory papillae on the tongue in Anatolian Water Buffalo. The filiform papillae were observed on the apex and body of the tongue, besides randomly identified lateral surface of the body. The conical papillae differed from the filiform papillae with its larger size and non existence of the secondary papillae. The fungiform papillae was round in shape and mushroom-like, scattering among the filiform papillae on the dorsal surface of the apex, body and the root of the tongue. The fungiform papillae's taste pores and creter-like structure were determined. The lentiform papillae were determined in two types. The borders of the cells and the micro-pitted appearance were defined at the lentiform papillae. In the vallate papillae bud fosse and a thick annular pad was found. These differences on the morphological structures of the lingual papillae were considered to be related to genetic diversity.

KEY WORDS: Anatolian water buffalo; Lingual papillae; SEM.

\section{INTRODUCTION}

The lingual mucosa of animals presents differentiated papillary system with gustatory and mechanical functions. Types of the lingual papilla and their distribution types have been examined in cattle (Steflık et al., 1983; Chamorro, 1986; Scala et al., 1995), serows (Funato et al., 1985; Atoj1 et al., 1998), camel (Qayyum et al., 1988), buffalo (Scala et al., 1993), Saanen goat (Kurtul \& Atalgın, 2008), roan antilobe (Emura et al., 2011), using scanning electron microscopy.

Anatolian Water Buffaloes have been scattered throughout all regions of Anatolia of Turkey. They are shaped as sparsely hairy with crooked horns. Studies which were about Anatolian Water Buffaloes which have been fed for delicious milk and skimming have been insufficient.

The present study has aimed to study the morphostructural differences of the tongue in the Anatolian water buffalo.

\section{MATERIAL AND METHOD}

Tongues were collected from six young male water buffaloes (1 years old, approximately $200-250 \mathrm{~kg}$ in weight and with a known pedigree) immediately after slaughter in a local slaughterhouse at Balıkesir.

Tissue samples were taken dorsal, ventral and lateral surface of the apex, body and root of the tongue. The samples were then rinsed with phospate buffer $(\mathrm{Ph}=7.2)$ and prefixed in $2.5 \%$ gluteroldehyde solution. After dehydration through a graded ethanol series, and infiltration by hexamethyldisilasin (HMDS). For the SEM, materials were fixed on aluminum stubs using double-sided adhesive. The SEM micrographs were taken in a SEM-JEOL (JCM 5000) at an accelerating voltage of $10-15 \mathrm{kV}$.

\section{RESULTS}

Macroscopic observations: The tongues of the Anatolian water buffaloes were long, broad and blunt. The tongue of the Anatolian water buffalo was $33 \mathrm{~cm}$ long, $6 \mathrm{~cm}$ in width apex, $6.5 \mathrm{~cm}$ at the body and $7 \mathrm{~cm}$ at the root of the lingua on average. Filiform, lentiform, fungiform, vallate and conical papillae were determined on the dorsal and ventrolateral surfaces of the tongue in Anatolian water 
buffalo. The vallate papillae number were 23 and fungiform papillae 342 , lentiform papillae were 241 on average. The filiform papillae numbers were 33 per $\mathrm{cm}^{2}$ area.

Scanning electron microscopy: Numerous filiform papilllae (Figs. 1 and 2) were observed on the apex and body of the tongue and randomly determined lateral surface of the apex of the tongue. Filiform papilllae were different heights, thicknesses and width the same region. The filiform papillae occured only in larger main papilla. The filiform papillae had no secondary papillae (Figs. 1 and 2). There were no secondary papillae at the lateral surface of the tongue, either. The height of the filiform papillae varied between 780 and $920 \mu \mathrm{m}$ and width between 312 and 422 $\mu \mathrm{m}$. The height and width of the filiform papillae showed substantial differences. The filiform papillae distributing on the dorsal surface at body of the tongue had round shape tips. The surface layer of the epithelium of the filiform papillae was highly keratinized, particularly at the rostral aspect of the papillae.

The conical papillae were found on the torus linguae and ventro-lateral surface of the lingual mucosa. These papillae differed from the filiform papillae with their larger size, nonappearance of secondary papillae and a tip without projections. These papillae were observed with round shaped base and a pointed tip. Especially, the conical papillae on the ventro-lateral surface of the lingual mucosa had been bulbous round shape base and very pointed tips. The papillae appeared to emerge from the lingual mucosa without a groove at their base. Their surface was covered with squamous epithelial cells. No taste buds and pores were observed on the surface of these papillae.

The fungiform papillae (Figs. 2 and 3) were round in shape and mushroom-like, scattering among the filiform

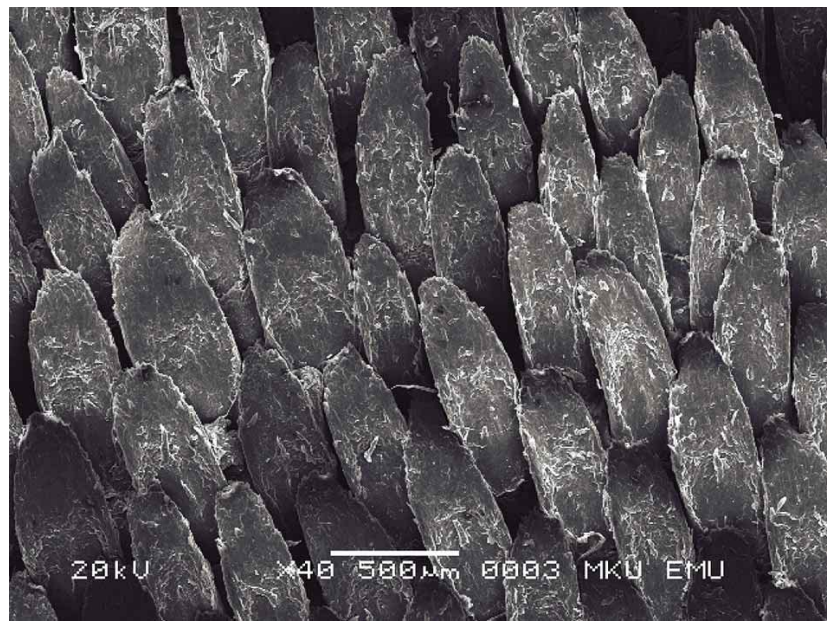

Fig. 1. Apex lingua. Filiform papillae without secondary papillae. papillae on the dorsal surfaces of the apex, body, the root and ventral surface of the lingua. Desquamated epithelial cells and micro-ridges were observed at the free surface. Pores with crater like structure were recognizable on the free surface of the fungiform papillae at x2000 magnification. These pores had a diameter of approximately $5 \mu \mathrm{m}$.

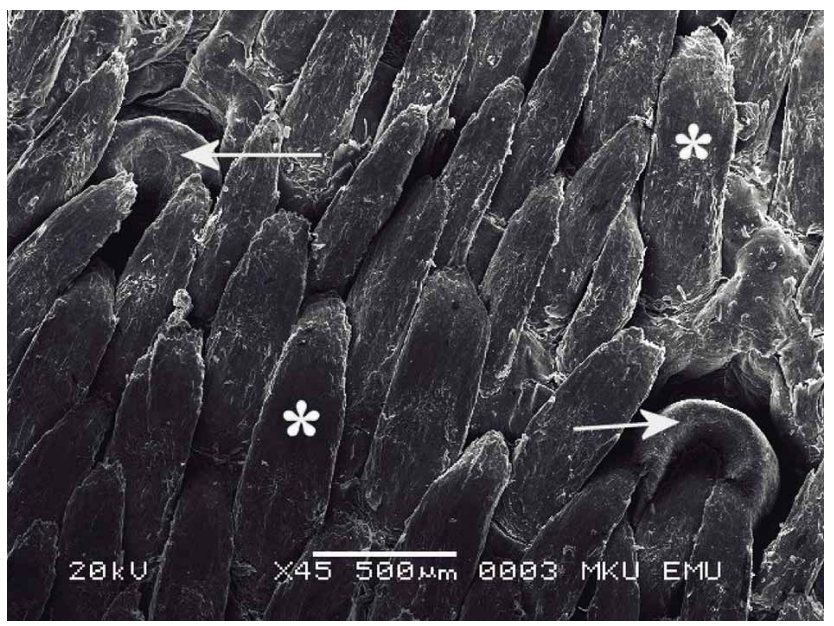

Fig. 2. Filiform papillae (asterissk) and fungiform papillae (arrows).

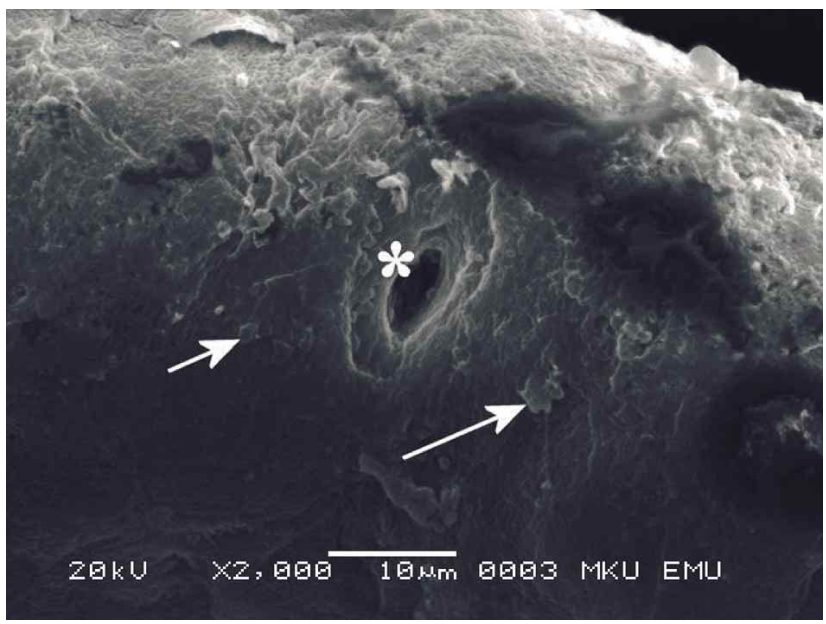

Fig. 3. Fungiform papilla, squamous epithelial cells sheddings (arrows), gustatory bud pore (asterisk).

The lentiform papillae (Fig. 4) were lentil-like papillae of different diamater sizes $(0.7-1.4 \mathrm{~mm})$ and only observed on the torus linguae. These papillae were determined in two types. The irregular type I lentiform papilla middle of the torus lingua and it hadn't apex, the roundshaped type II lentiform papilla both sides of the torus lingua but had a pointed apex. There were no secondary papillae. The borders of the cells and the micro-pitted appearance were defined at the lentiform papillae clearly at x2000 magnification (Figs. 5 and 6). Epithelial cells had a pitted appearance typical of keratinized cells. Cell boundaries were prominent and overlapping. 
The vallate papillae were located symmetrically on either side of the torus linguae where girdling by a gustatory bud ditch and thick annular pad or vallium of lingual muco-

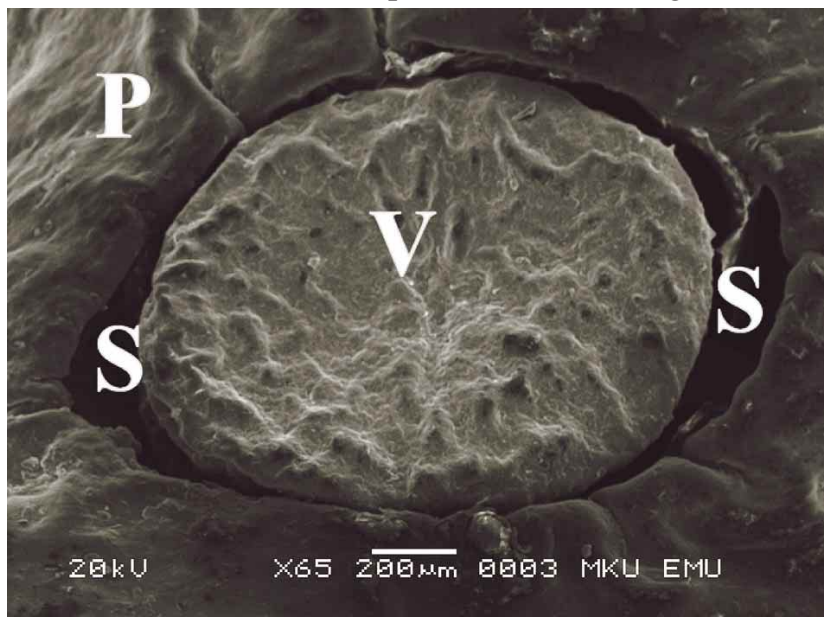

Fig. 4. Vallata Papilla (V); its sulcus (S) and pads (P).

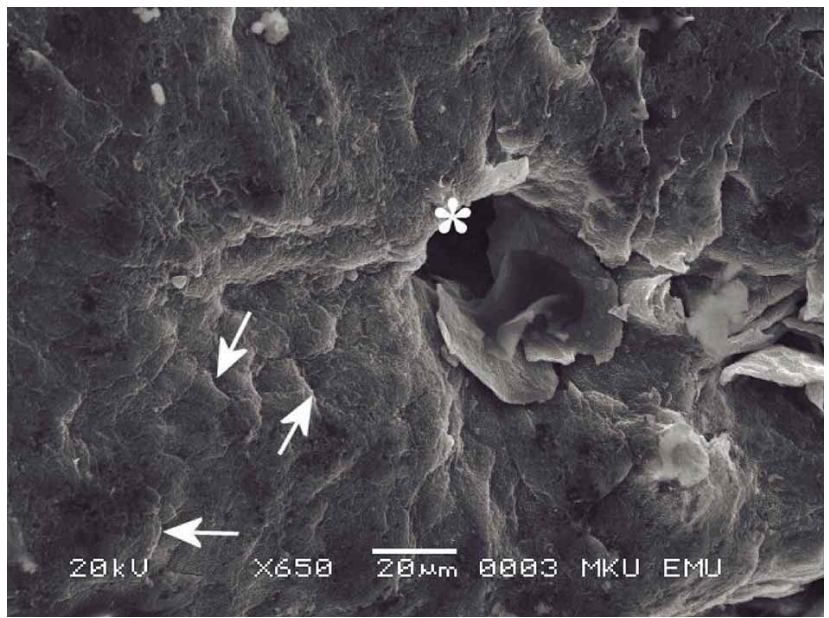

Fig. 5. Lentiform papilla, taste pore (asterisk) and cell boundaries (arrows).

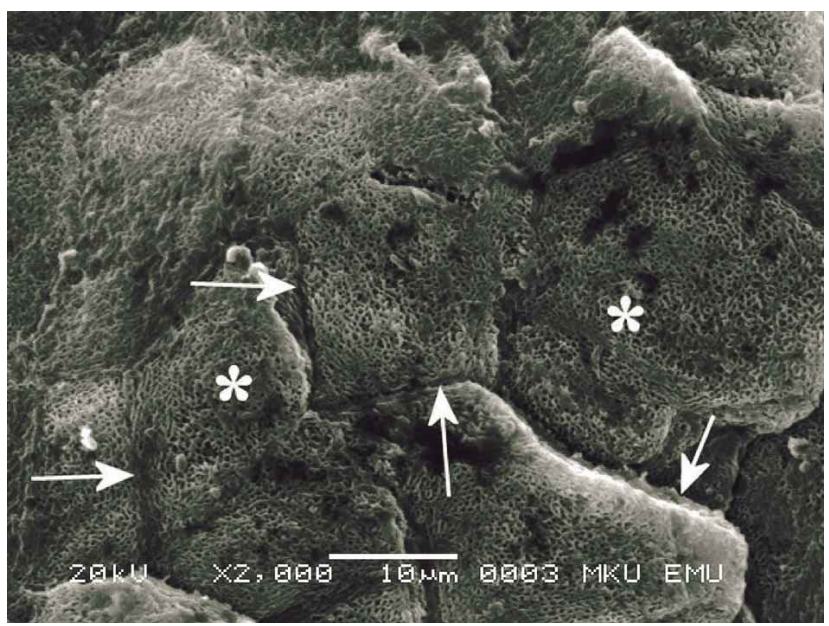

Fig. 6. Lentiform papilla, the borders of the cells (arrows) and the micro-pitted patterns (asterisk). sa (Figs. 7 and 8 ). The vallium was split into $2-3$ portions by small furrows. These round shaped papillae located caudally larger than those lying cranially. The vallate papilla was 1320 $\mu \mathrm{m}$ in diameter on average.

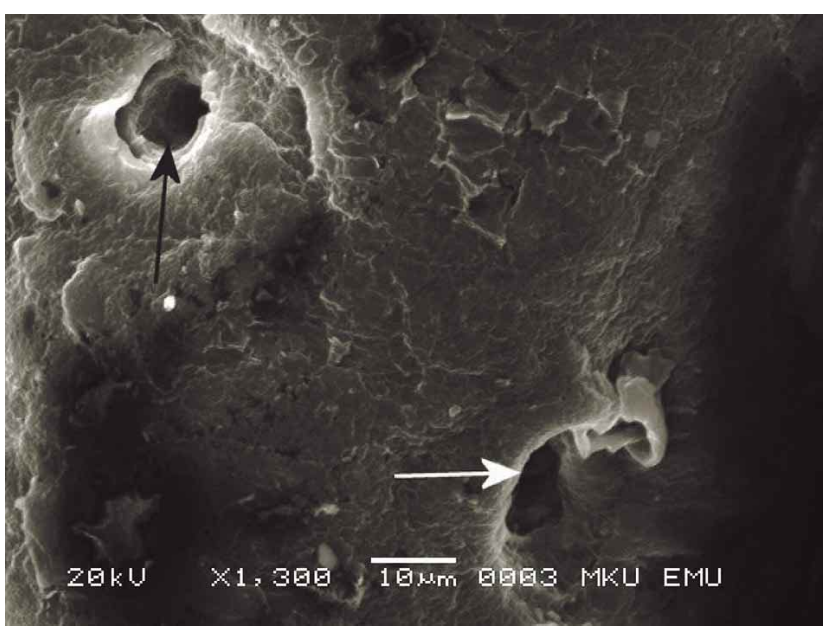

Fig. 7. Taste pores (arrows) on the upper surface of a vallata papilla as a crater-like structure.

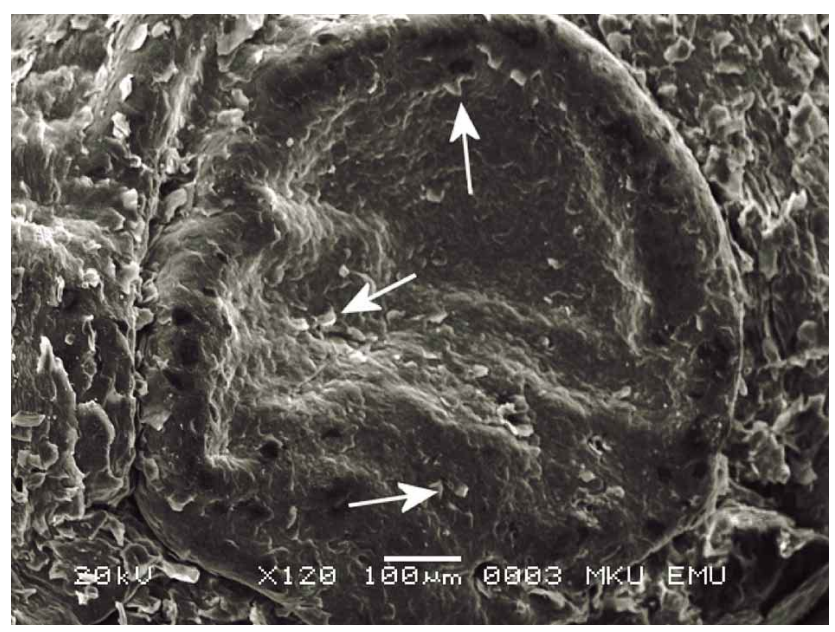

Fig. 8. Lentiform papilla, squamous epithelial cells sheddings (arrows).

\section{DISCUSSION}

In this study, the anatomical characteristics of the lingual papillae in Anatolian water buffalo was investigated, using scanning electron microscopy techniques. And the findings were compared to research conducted previously on the papillae of the tongue.

The filiform papillae on the dorsal surface of the lingua showed in this study as informed in the buffalo (Scala et al., 1993) and Jamunapari goat (Emura et al., 2011). The filiform papillae had oval tips. Unlike our results, these 
papillae have one sharp pointed tip in the cow (Chamorro et al.) and Jamunapari goat (Emura et al., 2011). Secondary papillae of filiform papillae were reported in the Jamunapari goat (Emura et al., 2011) and other articles (Sonntag 1925; Agungpiriyono et al., 1995). One of the important results of the study was that secondary papillae of filiform papillae were not found and this was different from other studies (Agungpiriyono et al.; Dyce et al., 2004; Emura et al., 2011). In some studies there had been bifurcated tips and each filiform papillae had a lot of secondary papillae. But it was not bifurcated tips in this study. The present study showed the lack of secondary papillary projections in the filiform papillae of Anatolian water buffalo similar to one humped camel tongue (Quayyum et al., 1988). The filiform papillae form a mildly rough surface, which enables careful mastication and handling of food before swallowing.

The small filiform papillae were showed on the ventro - lateral surface of the lingua were much less dense, had a distinct basal groove, and possessed no secondary papilla at the near and base too.

The fungiform papillae were showed in this study similar to those documented in the cow (Chamorro et al. 1986) and Jamunapari goat (Emura et al., 2011). Parallel to the statement in Jamunapari goat (Emura et al., 2011), there were fungiform papillae on the dorsal surface of the lingua and pores were identified at x2000 magnification in this study. These papillae were spread among the filiform papillae, and separated by a marked papillary groove. The fungiform papillae were more densely distributed on the tip and ventral surface of the lingual apex in the study, as to Japanese serow (Funato et al.), Formosan serow (Atoji et al.), Blackbuck (Emura et al., 1999) and Barbary sheep (Emura et al., 2000). The appearance of the taste on fungiform papilla at x650 magnifications similar to some articles (Kullaa-Mikkonen \& Sorvari, 1985; Adnyane et al., 2011; Ates et al., 2013). But it was not seen in other studies (Steflik et al.; Dyce et al.).

The lentiform papillae were located on the dorsal aspect of the lingua as reported in cow (Scala et al.) and the Jamunapari goat (Emura et al., 2011). There were two types of lentiform papillae. First papilla named irregular type I lentiform papillla, had one or two sharp tips, others named round shaped type II lentiform papilla had surrounding annular groove. Micro-pitted image of papillae were found due to the keratinized cells. In human oral mucosa the non-keratinized seem to have surface microplication (Kullaa-Mikkonen \& Sorvari), while keratinized surface has a pitted appearance called micro-pits (Adnyane et al.). On the Anatolian water buffalo lingua the epithelium of the lentiform papillae, fungiform papilla and filiform papilla were keratinized (pitted). Because the upper surface of papillae, filiform, fungiform, lenticular papillae, lack the protection of seconder papillae and because that surface comes into contact with foods, epithelium comes keratinized as a response to the environmental stress. Epithelial cells of lentiform papilla had a pitted appearance typical of keratinized cells. Cell boundaries were prominent and overlapping similar to a study (KullaaMikkonen \& Sorvari).

Micro-pits systems, which were reported (Kumar et al., 1998; Adnyane et al.) in the filiform and lentiform papillae were determined on the surface of the lentiform papillae the borders of the cells and the micro-pitted patterns in this study at x2000 magnification.

Morphostructure and location of the conical papillae were similar to those in the cow (Chamorro et al.), and Jamunapari goat (Emura et al., 2011). The conical papillae on the ventro-lateral surface of the lingual mucosa had bulbous round shape base and very pointed tips. In this study it wasn't seen secondary papillae near the conical papilla was not seen as reported by the literature (Chamorro et al.; Kumar et al.).

The vallata papillae had surrounding thick annular fold and our findings are similar to the literature in cow (Chamorro et al.), Jamunapari goat (Emura et al., 2011) and wild pig (Ates et al.). It is well known that the number and spread of the vallate papillae varied between species from being entirely absent, as in single in mouse, rat and hamster (McMillan, 1979) to numerous as in ruminants (Chamorro et al.; Scala et al.; Kumar et al.; Tadjalli \& Pazhoomand, 2004; Kurtul \& Atalgın).

Results of this study indicated that Anatolian water buffalo linguae were equipped with lots of papillae with different morphological features. These linguae had mechanical function which was similar to one humped camel (Quayyum et al.), Saanen Goat (Kurtul \& Atalgın), sheep (Sah Harem et al., 2009) and Jamunapari goat (Emura et al., 2011).

ACKNOWLEDGEMENTS. The authors would like to thank to Basic Sciences Research and Applied Center of Mustafa Kemal University and Balikesir University for scanning electron microscopy.

CAN, M. \& ATALGIN, S. H. Estudio de las papilas linguales en el búfalo de agua de Anatolia por microscopía electrónica de barrido. Int. J. Morphol., 33(3):855-859, 2015.

RESUMEN: El objetivo de este estudio fue describir la estructura de la superficie de las papilas linguales en Búfalos de agua de Anatolia mediante microscopía electrónica de barrido (MEB). Se utilizaron seis Búfalos machos para el estudio. Se determinaron tres tipos de papilas mecánicas: filiformes, lenticular y cónicas. También se en- 
contraron papilas gustativas de dos tipos: fungiformes y caliciformes. Las papilas filiformes se localizaron en el vértice y cuerpo de la lengua, además de encontrarse con una distribución al azar en la superficie lateral del cuerpo lingual. Las papilas cónicas se diferenciaron de las filiformes por su mayor tamaño y la ausencia de papilas secundarias. Las papilas fungiformes presentaban una forma redonda, similar a un hongo, con una distribución entre las papilas filiformes en la superficie dorsal del vértice, cuerpo y la raíz de la lengua. Además se observaron poros gustatorios en las papilas fungiformes con estructura similar de cráter. Las papilas lenticulares se determinaron en dos tipos. Se definieron los márgenes celulares y aspecto de micro corrosión en las papilas lenticulares. En las papilas circunvaladas se observaron brotes excavados y una almohadilla anular gruesa. Se consideró que estas diferencias en las estructuras morfológicas de las papilas linguales están relacionadas con la diversidad genética.

PALABRAS CLAVE: Búfalo de agua de Anatolia; Papilas linguales; Microscopía electrónica de barrido.

\section{REFERENCES}

Adnyane, I. K.; Zuki, A. B.; Noordin, M. M. \& Agungpriyono, S. Morphological study of the lingual papillae in the barking deer, Muntiacus muntjak. Anat. Histol. Embryol., 40(1):73-7, 2011.

Agungpriyono, S.; Yamada, J.; Kitamura, N.; Nisa, C.; Sigit, K. \& Yamamoto, Y. Morphology of the dorsal lingual papillae in the lesser mouse deer, Tragulus javanicus. J. Anat., 187(Pt. 3):635-40, 1995.

Ates, S.; Akaydin Bozkurt, Y.; Kozlu, T; Alan, A. \& Düzler, A. Light and scanning electron microscopic studies on the lingual papillae of 80-dayold wild pig fetal siblings. Turk. J. Vet. Anim. Sci., 37:664-71, 2013.

Atoji, Y.; Yamamoto, Y. \& Suzuki, Y. Morphology of the tongue of a male Formosan serow (Capricornis crispus swinhoei). Anat. Histol. Embryol., 27(1):17-9, 1998.

Chamorro, C. A.; de Paz, P.; Sandoval, J. \& Fernandez, J. G. Comparative scanning electron-microscopic study of the lingual papillae in two species of domestic mammals (Equus caballus and Bos taurus). 1. Gustatory Papillae. Acta Anat. (Basel), 125(2):83-7, 1986.

Dyce, K. M.; Sack, W. O. \& Wensing, C. J. G. Tratado de Anatomia Veterinária. 3rd ed. Rio de Janeiro, Elseiver, 2004. pp.364-8.

Emura, S.; Okumura, T. \& Chen, H. Morphology of the lingual papillae in the roan antelope. Okajimas Folia Anat. Jpn., 88(3):127-31, 2011.

Emura, S.; Tamada, A.; Hayakawa, D.; Chen, H.; Yano, R. \& Shoumura, S. Morphology of the dorsal lingual papillae in the blackbuck, Antilope cervicapra. Okajimas Folia Anat. Jpn., 76(5):247-53, 1999.

Emura, S.; Tamada, A.; Hayakawa, D.; Chen, H. \& Shoumura, S. Morphology of the dorsal lingual papillae in the barbary sheep, Ammotragus lervia. Okajimas Folia Anat. Jpn., 77(2-3):39-45, 2000.

Funato, H.; Atoji, Y.; Suzuki, Y. \& Sugimura, M. Morphological studies on the tongue of wild Japanese serows, Capricornis crispus. Res. Bull. Fac. Agr. Gifu Univ., 50:205-19, 1985.
Kullaa-Mikkonen, A. \& Sorvari, T. E. A scanning electron microscopic study of the dorsal surface of the human tongue. Acta Anat. (Basel), 123(2):114-20, 1985

Kumar, P.; Kumar, S. \& Singh, Y. Tongue papillae in goat: a scanning electron-microscopic study. Anat. Histol. Embryol., 27(6):355-7, 1998.

Kurtul, I. \& Atalgin, S. H. Scanning electron microscopic study on the structure of the lingual papillae of the Saanen goat. Small Rumin. Res., 80(1-3):52-6, 2008.

McMillan, M. D. The surface structure of the completely and incompletely orthokeratinized oral epithelium in the rat: a light, scanning and transmission electron microscope study. Am. J. Anat., 156(3):33751, 1979.

Quayyum, M. A.; Fatani, J. A. \& Mohajir, A. M. Scanning electron microscopic study of the lingual papillae of the one humped camel, Camelus dromedarius. J. Anat., 160:21-6, 1988.

Sah Harem, I.; Karadag Sari, E.; Kocak Harem, M. Light and scanning electron microscopic structure of dorsal lingual papillae of the Akkaraman Sheep. Kocatepe Vet. Derg., 2(2):8-14, 2009.

Scala, G.; Mirabella, N. \& Pelagalli, G. V. Morphofunctional study of the lingual papillae in cattle (Bos taurus). Anat. Histol. Embryol., 24(2):101-5, 1995.

Scala, G. ; Pelagalli, G. V.; Vittoria, A. \& de Girolamo, P. Morphostructural study of the lingual papillae in the buffalo (Bubalus bubalus). Anat. Histol. Embryol., 22(3):264-72, 1993.

Sonntag, C. F. The comparative anatomy of the tongues of the mammalia.-XII. Summary, classification and phylogeny. Proc. Zool. Soc. Lond., 95(2):701-62, 1925.

Steflik, D. E.; Singh, B. B.; Mckinney, R. V. Jr. \& Boshell, J. L. Correlated TEM, SEM, and histological observations of filiform papillae of the cow tongue. Acta Anat. (Basel), 117(1):21-30, 1983.

Tadjalli, M. \& Pazhoomand, R. Tongue papillae in lambs: A scanning electron microscopic study. Small Rumin. Res., 54(1-2):157-64, 2004.

\author{
Correspondence to: \\ Dr. S, ükrü Hakan Atalgin \\ Balıkesir Üniversitesi \\ Veteriner Fakültesi \\ Anatomi ABD, Çag`ıs, Kampüsü \\ Balıkesir \\ TURKEY
}

Email: mehmetcan4310@hotmail.com sukruhakan@hotmail.com

Received: 18-02-2015

Accepted: 02-06-2015 